\title{
When PPP Meets Asset Securitization-The First PPP Experience Enlightenment Project of Asset-Backed Special Programs
}

\author{
Jing He \\ School of Management, Jinan University, Guangzhou, China \\ Email: hejing5630@163.com
}

How to cite this paper: He, J. (2019) When PPP Meets Asset Securitization-The First PPP Experience Enlightenment Project of Asset-Backed Special Programs. Open Journal of Social Sciences, 7, 120-131. https://doi.org/10.4236/jss.2019.712010

Received: November 11, 2019

Accepted: December 3, 2019

Published: December 6, 2019

Copyright ( 2019 by author(s) and Scientific Research Publishing Inc. This work is licensed under the Creative Commons Attribution International License (CC BY 4.0).

http://creativecommons.org/licenses/by/4.0/

\section{(c) (i) Open Access}

\begin{abstract}
PPP mode as the government and the community to provide new capital cooperation mode of public goods and public services, attracted widespread attention in recent years. The theory and practice of asset securitization can revitalize the stock of assets, improve PPP flow of project assets, innovation PPP refinancing and social capital exit channels, an effective solution to PPP financing difficulties faced stimulates investment enthusiasm, both natural fits of the long term asset securitization are PPP inevitable development of the project trend. Taking the first four PPP project asset support special plans in 2017 as an example, this paper analyzes the "PPP + ABS" innovative public utility project financing mode from the aspects of necessity and value, basic assets, transaction structure design, credit enhancement, etc., points out the existing problems in the current PPP project asset securitization financing. This innovative public utility project financing noted the current PPP securitization financing problems in project assets, raised about how to use the asset securitization financing tool to help PPP policy recommendations to promote the safe and orderly project.
\end{abstract}

\section{Keywords}

PPP Projects, Asset Securitization, Project Financing

\section{Introduction}

PPP (Public-Private Partnership), a partnership between government and social capital, also known as the PPP model, refers to long-term partnerships in infrastructure and public services. Under this model, private capital is encouraged to participate in the construction of public infrastructure, and the government has 
formed a partnership of "interest sharing, risk sharing, and full cooperation" [1]. The most important feature of the public-private partnership model is the introduction of the private sector into the public domain, thereby improving the efficiency of public facilities services and avoiding the drawbacks of excessive investment, delays in construction, and poor quality of service. In 2014, the term PPP first appeared in the central government documents, marking that China's application of the PPP model in the public service sector has entered a new stage of development. With the introduction of intensive series of policies and regulations, China's PPP model is standardized and orderly progress, from top to bottom of the PPP warm mode remains high, As of the end of February 2019, the Ministry of Finance PPP Center had 12,597 PPP warehousing projects; the total investment amount was 1762.7 billion yuan; and the project landing rate (the ratio of the sum of the number of projects in the two phases of implementation and transfer to the number of management warehouse projects) is about $56.63 \%$ [2].

The PPP model is a long-term undertaking that redefines the relationship between government and society, introduces market mechanisms into the political arena, and adopts competitive methods to bring private capital into the public domain [3] [4], allowing non-public sector resources to participate. In the past, only the products and services provided by the public sector could improve the level and efficiency of the supply of public goods and public services. At the same time, it also has important significance in promoting the transfer of government functions from "boating" to "steering" and improving the level of national governance. At present, China's PPP practice reveals a series of problems and difficulties in operation, of which the most prominent is the financing channel and is not smooth, the financing cost is high and the financing is difficult. Capital is an important basis for the construction and operation of PPP projects, to broaden the PPP project financing, Solving the financing problem of PPP projects is a top priority. In December 2016, the Commission and the National Development and Reform Commission jointly issued "on promoting social capital and government cooperation in the field of traditional infrastructure (PPP notification) asset securitization project related work", has aroused for PPP project of asset securitization close attention. "PPP + ABS" for the government to inject capital in cooperation with the community new life, as the first batch of government and social capital cooperation projects successful securitization of financing for future PPP provides an important reference project for sustainable development of asset securitization.

\section{PPP Project Financing and Asset Securitization}

\subsection{PPP Project Financing}

Project financing is a financing model that raises funds for project construction or operation based on the future income or assets of the project and the future cash flow generated by the project operation as the source of repayment. The PPP model is a project implementation model that has been promoted by the 
state in recent years. The financing activities of project companies jointly established by the government and social capital reflect the essential characteristics of project financing. Project financing is different from traditional corporate financing based on the main credit level. It has low dependence on the project sponsor's credit level and pays more attention to the project's own operation status. Therefore, the quality project can have a higher credit level than the project sponsor. Have better financing ability. The PPP project has a large investment scale, a long period of time, basically stable demand, and the characteristics of government credit, laying a foundation for asset securitization financing.

\subsection{The Necessity and Value of "PPP + ABS"}

Financing dilemma. PPP government and social capital to work together for the common mode of operation of the infrastructure project force, which doomed the P PP project financing with the traditional project finance has inherent different, reflecting the unequal participation in legal relations subject, full life in Cycle financing, large capital demand, long investment return period, high positive externalities, low yields, etc. [5], the characteristics of PPP projects determine that it faces greater difficulties in financing. The main constraint factor for the low rate of signing the PPP project in China is the problem of financing difficulties. In the project initiation phase, shareholders invested capital is PPP basis for project financing, subsequent construction and operation phase requires ongoing capital investment, debt financing is PPP important part of the follow-up financing of projects, mainly through bank loans and bond issues the way. In the most common BOT model, the project has a long construction period, during which there is almost no cash flow, the financing risk is high, and the PPP project participants are both numerous and mixed, and the credit level and performance capability of each entity. It also directly affects the project's profitability and solvency. For the fund provider, higher risk means higher risk compensation, which actually limits the financing scale of the PPP project and increases the financing cost. Another important issue is debt financing, PPP project because of its lack of existing assets, and is usually in the form of project financing to yield notes and project revenue bonds, but because of PPP project company over a long period of time cannot become The issue of qualified issuers is difficult to issue, and China's PPP projects rarely finance in this way. In addition, in the current domestic PPP practice, the lack of diversified exit mechanism of social capital also affects the enthusiasm of investors, and the financing dilemma restricts the development of PPP.

To fill the huge shortage of funds for new urbanization, and ease the financial pressure of local governments. March 16, 2014, Xinhua News Agency issued "new national urbanization plan (2014-2020 years)" (hereinafter referred to as "Plan"), "planning" that active the requirements and objectives and steadily push forward the construction of new urbanization: resident population urbanization rate has reached $60 \%$ or so. As China's urbanization level continues to increase steadily, railways, highways and other transportation facilities, infrastructure 
such as electricity, gas, water supply, sewage treatment, and construction of public service facilities such as schools, medical and health institutions, cultural facilities, and stadiums will further Strengthening, creating a large amount of investment demand, but also brought a huge funding gap, resulting in greater pressure on local government finances. On the one hand, "PPP + ABS" has innovated the way public goods and services are provided, and have opened up new implementation mechanisms for infrastructure construction. On the other hand, it has also solved the problem of weak infrastructure liquidity and financing difficulties. The funding gap promoted, effectively alleviating the pressure on local government fiscal expenditure.

Asset securitization can stimulate the vitality of PPP On March 5, 2019, Premier Li Keqiang said in his government work report. In 2018, the downward pressure on the domestic economy increased, consumption growth slowed down, and effective investment growth was weak. How to stimulate the vitality of social capital is an important and thorny issue in the comprehensive deepening of the reform process. The Ministry of Finance, the National Development and Reform Commission and other ministries and commissions have successively issued a number of policies to actively promote the PPP model in new urbanization projects and toll roads, and promote the combination of PPP and the "Belt and Road" to guide and support Chinese enterprises. Going out, deepening the reform and innovation of the investment and financing system, and a number of measures to expand the scope of social capital investment and stimulate the enthusiasm of social capital investment. However, in practice, although the PPP project has a relatively high investment scale, there is still a large gap between the project signing rate and the central expectation, mainly because the PPP project operation mechanism is more complicated, involving the multi-party's interest target coordination, lacking Flexible price adjustment mechanism, strong asset specificity, large project income uncertainty, and difficult financing and financing issues have limited the widespread application and promotion of PPP mechanism. Social capital based on risk management and control, investment in PPP project. Be cautious and lack enthusiasm. The asset securitization of the PPP project has added new channels for investors to revitalize existing assets, and use the capital market for market-based financing to improve the liquidity of assets, thereby improving the investor's ability to continue investing. By "PPP + APS" This financing mechanisms and financial products, enables PPP projects and effective convergence of capital markets for capital markets and PPP concerned is a win-win choice, on the one hand as the current number of many much-needed funding needs traditional PPP project to broaden the financing channels and sources of social capital, on the other hand can make capital market investors to share relevant PPP gains and dividends quality assets brought. PPP asset securitization to seize the financing key landing hard behind an effective solution to PPP financing projects to reduce PPP financing risky projects to stimulate the participation of social capital PPP enthusiasm for the project and, more importantly, to promote PPP mechanism Com- 
bined with guiding social investment and major national strategic projects, it stimulates effective investment growth and contributes to China's economic development.

\section{The First Batch of 4 Single PPP Project Asset Support Special Plan Case Analysis}

2017 is the first year of asset securitization of PPP projects in China. Thanks to the policy promotion of various departments and the high attention of the CSRC, in early March, the National Development and Reform Commission provided the CSRC with the recommendation of the first batch of 9 PPP asset securitization projects. A few days later, the Shenzhen Stock Exchange of the Shanghai Stock Exchange accepted 4 of them and issued a no-objection letter two days later. The basic situation of these four products is shown in Table 1.

The following four types of PPP project asset-backed securities will be analyzed from the basic assets of asset-backed securities, the benefit evaluation of PPP projects, transaction structure design and credit enhancement.

\subsection{Fundamental Assets of Asset-Backed Securities}

Asset securitization refers to the cash flow generated by the underlying assets as repayment support, credit enhancement through structured methods, and the issuance of asset-backed securities business activities [3], which can also be said to be the future of basic assets. "Structure + securitization" of cash flow. The basic assets mainly include credit assets, debt assets (accounts receivable, lease receivables, etc.), income rights assets (municipal charging rights, ticket income rights, PPP project income rights, etc.) As shown in Table 2.

PPP The main difference between the securitization of asset securitization and general infrastructure assets that the different characteristics of the underlying

Table 1. Overview of the asset support special program.

\begin{tabular}{|c|c|c|c|c|c|c|}
\hline \multicolumn{7}{|c|}{ Asset Support Special Plan Base Assets } \\
\hline Projects & $\begin{array}{c}\text { PPP Project } \\
\text { operation mode }\end{array}$ & $\begin{array}{c}\text { PPP Project } \\
\text { operation mode }\end{array}$ & Issue rate & $\begin{array}{l}\text { Issue size } \\
\text { (Million) }\end{array}$ & $\begin{array}{l}\text { Securities } \\
\text { rating }\end{array}$ & $\begin{array}{l}\text { The term } \\
\text { (Year) }\end{array}$ \\
\hline $\begin{array}{l}\text { CITIC Jiantou-Net New Investment and Qingchun Road } \\
\text { Tunnel PPP Project Asset Support Special Plan (Net New } \\
\text { Tunnel PPP) }\end{array}$ & BOT & Private placement & $4.05 \%-4.15 \%$ & 700 & AAA & 14 \\
\hline $\begin{array}{l}\text { CITIC Securities - Capital Creation PPP Project Charging } \\
\text { Revenue Rights Asset Support Special Plan (First PPP) }\end{array}$ & TOT/BOT & Private placement & $3.7 \%-4.6 \%$ & 530 & AAA & $1-18$ \\
\hline $\begin{array}{l}\text { Huaxia Happiness Gu'an Industrial Park New Urbanization } \\
\text { PPP Project Heating Charge Income Right Asset Support } \\
\text { Special Plan (Gu'an PPP) }\end{array}$ & BOT & Private placement & $3.9 \%-5.2 \%$ & 706 & AAA & $1-6$ \\
\hline
\end{tabular}


Table 2. Asset support special plan base assets.

\begin{tabular}{ccc}
\hline & Asset Support Special Plan Base Assets & \\
\hline Projects & Projects & Payment methods \\
\hline Wangxin tunnel PPPa & Contractual claims for franchise subsidy income & Government payment \\
Shouchuang PPP & Sewage treatment fee income right & Government payment \\
Guan PPP & Sewage treatment fee income right & User payment and Government payment \\
Hu men lv yuan & Heating charge income right & Government payment
\end{tabular}

assets: PPP underlying asset projects closely related to the franchise mode of operation is mainly BOT, TOT and other models, compliance Stronger and longer, it is suitable for securitization business in the stage of stable operation.

The first 4 basic single asset asset-backed securities in accordance with the contract subject to a different classification, are based PPP project company as the main issue. According to the classification of basic asset types, except for the PPP project of the new network tunnel, which is the contractual creditor's right, the other three orders belong to the income-rights assets. The payment methods are mainly government-paid, the sources of income are relatively stable and guaranteed, and the income-right assets are PPP asset securitization of the most important types of underlying assets. PPP project basic asset types are diverse, municipal basic assets (water supply, heating), transportation facilities construction basic assets (railway, highway, airport), development zone construction basic assets, characteristic town construction basic assets (such as Hefei PPP + VR + Featured towns, supported by the development of V R industry), basic assets in the field of environmental protection (sewage treatment), basic assets in the field of shed reform (special plan for asset support of Yangzhou Safe Housing Trust), basic assets of sponge city construction, etc. From the perspective of the main body of the contract, such as the PPP project loan of the commercial bank, the receivables of the PPP project company of the contractor/subcontractor are used as the basic assets. In the future, "PPP + ABS", a new financing method for public utility projects, can broaden the choice of basic assets, not necessarily limited to a certain type of assets, select and package high-quality basic asset types, restructure assets, and form asset pools.

\subsection{Project Benefit Evaluation}

Project financing is centered on its own profitability and solvency. Quality projects have better operational capabilities and profitability. For investors in the open market, the most important concern is the return on investment. Therefore, the project benefits Evaluation is an important part of PPP project assets for market financing. In PPP project selection and preparation phase, it will go through two core arguments: assessment of value for money and financial affordability. The former focuses on the relative evaluation, measuring whether the PPP model is more valuable than the traditional procurement model, and can 
reduce the project life cycle cost; while the latter is biased to assess the impact of the PPP project on current and future fiscal expenditures. According to the Shanghai and Shenzhen Stock Exchange, PPP project asset-backed securities listing requirements of the conditions, PPP project must have been built and operated a project, and therefore the initial stage of the project relating to value for money and financial affordability argument will not go, Focus on the future cash flow calculation of the project. The first batch of 4 payment methods is mainly the government payment mode. The basic assets are mainly public utilities, and the sources of income are relatively stable. The projects have been completed and have been operating normally for more than 2 years, and the payment status is good.

According to the report issued by Zhongxing Caiguanghua Certified Public Accountants, the basic factors involved in the cash flow forecast of Huaxia Happiness - Gu'an Heating Business include: the total area of residential heating section, heating rate and charging standard (according to the local price department's skin) The central heating charge standard is implemented. First, some basic data of cash flow forecasting are confirmed, and then the factors affecting cash flow forecasting are split, weighted, and analyzed. Finally, data adjustments are made based on events that are highly likely to have an impact on cash flow during the lifetime. It is predicted that the heating income of Jiutong Public Utilities will be 551.4435 million yuan from 2017 to 2022. Under normal circumstances, the cash flow coverage multiple is more than 1.1 times. Under pressure, the coverage multiple is also more than 1 times. The forecasted cash flow can cover special items. The principal and interest of the plan can ensure normal payment. The cash flow forecast and stress test of Humen Luyuan, Pioneer PPP and Net New Tunnel PPP project show that under normal circumstances, the forecasted cash flow of each period of basic assets can maintain the coverage multiple of the asset support special plan and above 1.1 times. And under pressure conditions, it is expected to be repaid normally, and the guarantee is in good condition. It can be seen that high-quality projects, with the ability to generate profits through continuous operations, can protect the interests of investors, and are the basis for the successful issuance of special-planned securities.

\subsection{Transaction Structure Design of the Asset Support Special Plan}

PPP main agencies involved in asset securitization projects include: originator, program managers/sales agency, asset custodian, bank supervision, registration and trusteeship agencies and intermediaries (accounting firms, law firms, credit rating agencies etc.), 4 concrete design projects proposed transaction structure, although slightly different, but the overall framework shown in Figure 1 . The subscribers entrust the plan manager with the agreement to sign the agreement with the plan manager through the asset support special plan. The 

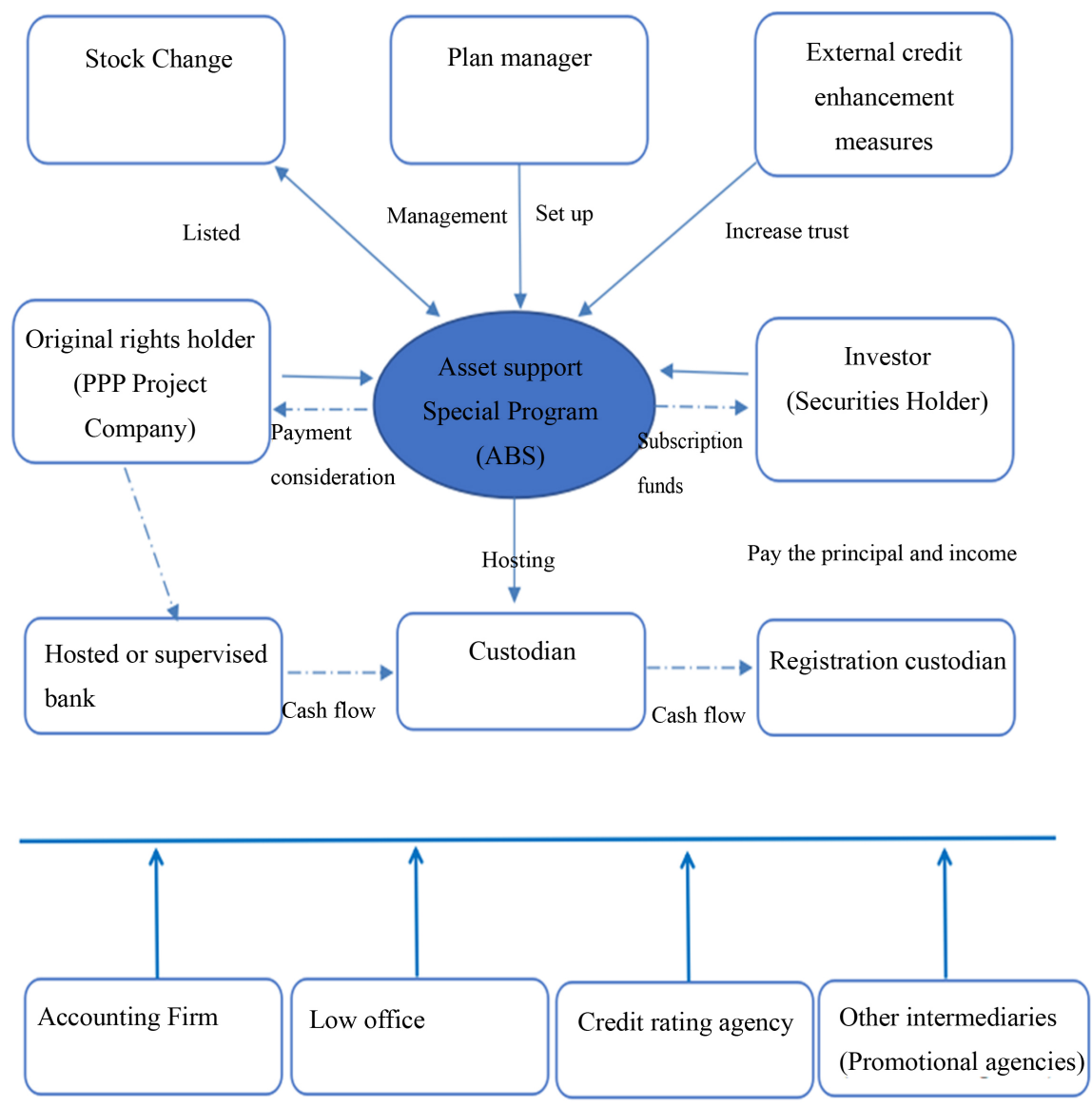

Figure 1. Asset management special plan transaction structure design.

plan manager establishes and manages the special plan to raise funds to purchase the base assets from the original equity. The investor becomes the holder of the security and the original owner obtains the purchase price. During the duration of the special plan, the original equity owner's operation and management earned income, and after the cash flow was collected, it was transferred to the investor to pay the securities principal and income.

\subsection{Credit Enhancement of the Special Plan}

The repayment of the special plan is supported by the cash flow recovery generated by the underlying assets. The underlying assets of the income category are uncertain in the time and distribution of the cash flow recovery, and the asset securitization is formed through the real sale. Cash flow is only related to specific business or creditor's rights in the asset pool, and its default risk is relatively high. The role of credit enhancement measures is to improve the credit quality of assets, achieve the credit level required for issuance, and reduce the cost of credit evaluation. In addition to saving capital financing costs, it also plays an important role in protecting the interests of investors and improving the liquidity of securities.

Credit enhancement includes internal credit enhancement and external credit 
enhancement. Internal credit enhancement is realized through trading structure design, adjustment of securitization structure and reallocation of cash flow, including securities priority/inferior level stratification, excess cash flow coverage, excess mortgage, margin/cash reserve account, etc. External credit enhancement usually uses third-party guarantee, mainly institutional guarantee, balance payment commitment, repurchase commitment and liquidity support. The credit enhancement measures of the first four special plans are shown in Table 3.

The four single product credit enhancement measures have adopted priority/secondary structured arrangements, cash flow over-coverage, differential payment commitment, repurchase/redemption guarantee support, etc., the first PPP, Gu'an PPP and mobile Sexual support, the adoption of multiple internal and external enhancement measures provides a higher level of credit guarantee for the asset support special program, and the securities rating is AAA level, which increases the possibility of trial.

\subsection{Summary}

Through the above analysis of the basic elements of the special plan, we can find that the four-single asset support special plans have the following characteristics:

The basic assets are mainly income-based assets. The core of the PPP project is public-private partnership, based on the franchise agreement signed by the government and the social capital. However, the franchise has a large policy restriction as the transfer of the underlying assets. Compared with franchise, the future income right of project management is transferable. The utilities involved in the PPP project usually have a stable user base and paying entities for a long period of time. They can continue to generate independent and predictable cash flows. As a basic asset, the right of return has more attempts in the development of asset securitization in China, which is relatively mature. in the development of China's asset securitization, which is relatively mature. However, as noted above, PPP project has a wealth of asset types based on research and analysis in depth, expanding PPP project assets securitized pool of assets, so that the value of high-quality assets to be fully reflected.

The issue rate is lower. The highest interest rate of the priority product is $3.7 \%$, and the highest interest rate is $5.2 \%$. Compared with the securitization of

Table 3. Asset support special plan credit enhancement measures.

\begin{tabular}{ccccccc}
\hline \multicolumn{7}{c}{ Asset Support Special Plan Credit Enhancement Measures } \\
\hline Project & $\begin{array}{c}\text { Priority/ } \\
\text { Secondary }\end{array}$ & $\begin{array}{c}\text { Cashflow } \\
\text { excesscoverage }\end{array}$ & $\begin{array}{c}\text { Differential payment } \\
\text { commitment }\end{array}$ & $\begin{array}{c}\text { Repurchase/ } \\
\text { Redemption Commitment }\end{array}$ & $\begin{array}{c}\text { Fluidity } \\
\text { Standby }\end{array}$ & $\begin{array}{c}\text { Third } \\
\text { party guarantee }\end{array}$ \\
\hline WangXin Tunnel PPP & $\sqrt{ }$ & $\sqrt{ }$ & $\sqrt{ }$ & $\sqrt{ }$ & $\times$ & $\times$ \\
ShouChuang PPP & $\sqrt{ }$ & $\sqrt{ }$ & $\sqrt{ }$ & $\sqrt{ }$ & $\sqrt{ }$ & $\times$ \\
GuAn PPP & $\sqrt{ }$ & $\sqrt{ }$ & $\sqrt{ }$ & $\sqrt{ }$ & $\times$ & $\sqrt{ }$ \\
HumenLvyuan & $\sqrt{ }$ & $\sqrt{ }$ & $\sqrt{ }$ & & & $\times$ \\
\hline
\end{tabular}


ordinary assets, it is at a lower level in the market (the highest issuance rate of the enterprise $\mathrm{AB}$ priority securities is $9.15 \%$, the minimum issuance rate is $3.55 \%$, and the average issuance rate is $5.49 \%$ ) [4], which is PPP consistent feature of the project that belongs to the utility sector, its own profit rate is not high enough attractive to investors.

The term is longer. In terms of product term setting, full consideration should be given to the long-term nature of PPP projects, with each single product ranging from $6-18$ years, so as to effectively solve the problem of term mismatch between PPP projects and asset securitization products.

Risk isolation is limited. From the perspective of transaction structure design, the original equity assigns the income right of the PPP project, and the special plan directly undertakes the basic assets of the PPP project. Since the PPP income right is attached to the original right holder's franchise, it is in the original when the equity party goes bankrupt, the special plan will not be able to enjoy the income right separately, resulting in the investor's investment income falling through [5], and there are also relevant risk warnings in the plan specifications of each single product. "PPP + ABS" mode on the transaction structure design must further consider bankruptcy to isolate the problem.

The issuance efficiency is high. The issue rate of the first batch of PPP project asset-backed securities is much faster than that of traditional asset securitization. This is mainly due to the top-down support of the policy, but whether it can be highly efficient after the policy dividend is removed from the market development. High-quality issuance depends on the improvement of trading mechanisms and processes.

Excessively relying on the original controller's guarantee and subject credit of the original equity holder, and adopting strong external credit enhancement measures, although it has achieved a higher rating, it ignores the essential characteristics of asset-backed products relying on the underlying asset cash flow.

\section{PPP Asset Securitization Related Recommendations}

The successful issuance of asset-backed securities of the first four PPP projects, PPP and ABS is a grand marriage of Finance and finance [3], an important step for public utilities to the capital market, when PPP projects encounter asset securitization, how to make both play harmoniously, work together, and find a broad road to asset securitization of PPP projects to meet domestic needs and characteristics? Based on the above analysis of the various elements of the asset support special plan and the characteristics of its implementation, the following suggestions are made in a targeted manner.

1) To strengthen top-level design, expedite PPP asset securitization laws, regulations and policy system. On the one hand, China issued a large number of PPP asset securitization relevant department regulations and normative documents, but the law is low level, and multi-sectoral released documents have mutual contradictions, to asset securitization business has brought practical diffi- 
culties, has been released policy documents and more from the overall control of the PPP project asset securitization business, normative, guiding role, but the lack of high-order legal norms and regulations specific intensive guidance. And the process of asset securitization involves complex accounting and tax treatment issues, and it needs to be clarified. On the other hand, from the perspective of investors and market supervision, project implementation information, securitization management and income distribution reports, and other information are timely and effective. disclosure is also extremely important to improve the information disclosure requirements, strengthen market supervision and improve PPP project transparency and reduce information asymmetry, ensure PPP project securitization business open and transparent, efficient capital markets play a supervisory function. In view of this, the legislative level to protect from PPP asset securitization law, the law to follow, is that the current PPP urgent needs securitization project assets.

2) Gradually enrich the basic asset types. Finance [2017] 55 No. document 10 states actively explore the future income right of the project company in the project construction period based on the PPP contract, the project put into operation 2 after shareholders of the project company may be able to bring equity to cash flow, The various creditors who provide financing support for the project company, as well as the contractors and other enterprises that provide construction support for the project company, act as promoters (original equity holders), and can issue asset securitization products as contractual claims and income rights. In addition, equity assets supporting "PPP + REITs" are used as the underlying assets of securitization. The ideal asset for securitization is a pool of assets consisting of a large number of small, low-relevant assets [6]. PPP project size is generally larger, considering the combination of different regions, different nature of the underlying assets, structural design, the formation of inter-regional cross-cutting pool of assets, such as the first shares sewage PPP asset-backed special programs, its originator. These include Linyi, Liangshan, Yucheng and Weinan Shouchuang Water Co., Ltd.

3) Explore the design of dual SPV transaction structure to effectively isolate risks. For PPP transfer restrictions franchise projects, the sale of real asset base, limited bankruptcy isolation problem, we can start from the design of the transaction structure, exploring the double $\mathrm{S}$ the PV transaction structure, made between the originator and the special purpose vehicle To effective risk isolation, break through the limits of the underlying asset cash flow. The so-called double-S the PV structure, that is, "the trust scheme + asset-backed special programs", PPP project sponsor will first design the underlying asset trust scheme, trust income to get right, this is the first layer of the transaction structure; and then plan the right of return as Trust The new basic assets, design asset support special plan, re-segment the corresponding cash flow, structure and reorganization, issue securities products, and explore the transaction structure of "financial leasing + asset support special plan". The CITIC Trust-Tangshan World Expo PPP project asset support special plan accepted on January 28, 2019, adopts the 
dual SPV structure design of property rights trust plus single fund trust loan, which has reference significance.

4) Improve the ability of the original equity holders to continue to operate and cultivate the net cash flow of the project. Relying on asset-backed special programs of the future cash flow, asset securitization of assets provides the basis withdraw financial investment channels of social capital, but that does not mean that social capital side from P PP get out of the project, which still needs Continue to assume responsibility for operation and maintenance, so that the underlying assets have sustained and stable profitability. On the one hand, starting from the optimization of income structure, bundling private products, developing by-products, such as advertising, authorizing the provision of ancillary services (greening, property), etc., extending the value chain, broadening the source of income, and optimizing the cost structure on the other hand, packaging and packaging of different projects. In order to achieve scale effect, reduce costs, combine upstream and downstream projects to achieve range effects, strict internal control, improve company and project governance, and innovate in management and technology to further optimize cost and expense structure.

\section{Conflicts of Interest}

The author declares no conflicts of interest regarding the publication of this paper.

\section{References}

[1] Wang, F.Q., Zhan, L. and Zhao, L. (2018) Global Progress of PPP and China's Reform Practice. China Financial and Economic Publishing House, Beijing.

[2] Ministry of Finance PPP Center (2019) National PPP Comprehensive Information Platform Project Management Library 2019.2.

[3] Lin, H. (2016) PPP and Asset Securitization. CITIC Publishing House, Beijing.

[4] China Government Securities Depository and Clearing Co., Ltd., Oriental Jincheng International Credit Evaluation Co., Ltd. (2018) 2018 Asset Securitization Development Report.

https://doc.mbalib.com/view/6e83a66b4033b019d61f7eef5e39af07.html

[5] Wu, L.C. (2017) Transfer of Income Rights and Bankruptcy Isolation in PPP Asset Securitization: Taking the First Batch of PPP Project Asset Support Special Plan as an Example. Securities Market Herald, 12-19.

[6] Wang, T.Y. and Han, Z.F. (2018) China PPP Annual Development Report (2017). Social Sciences Academic Press, Beijing. 